\title{
DIABETES AND MOTOR VEHICLE CRASHES: A SYSTEMATIC EVIDENCE-BASED REVIEW AND META-ANAL YSIS
}

\author{
Stephen J. Tregear, ${ }^{1}$ Matthew Rizzo, ${ }^{2}$ Marie Tiller, ${ }^{1}$ Karen Schoelles, ${ }^{1}$ \\ Kurt T. Hegmann, ${ }^{3}$ Michael I. Greenberg, ${ }^{4}$ Barbara Phillips, ${ }^{5}$ Gunnar Anderson ${ }^{6}$ \\ ${ }^{1}$ ECRI Evidence-based Practice Center, Plymouth Meeting, PA, USA \\ ${ }^{2}$ University of Iowa College of Medicine, Iowa City, IA \\ ${ }^{3}$ University of Utah College of Medicine, Salt Lake City, UT, USA \\ ${ }^{4}$ Drexel University College of Medicine, Philadelphia, PA, USA \\ ${ }^{5}$ University of Kentucky College of Medicine, Lexington, KY, USA \\ ${ }^{6}$ Rush University Medical Center, Chicago, IL, USA \\ E-mail: stregear@ecri.org; matthew-rizzo@uiowa.edu; mtiller@ecri.org; \\ kschoelles@ecri.org; Kurt.Hegmann@hsc.utah.edu; mgreenbe@drexelmed.edu; \\ BPhi195@aol.com; Gunnar_Andersson@rsh.net
}

\begin{abstract}
Summary: The primary objective of this systematic review was to address the question, "Are drivers with diabetes mellitus at greater risk for a motor vehicle crash than comparable drivers without the disease?" and secondarily, to address the question, "Are insulin-treated diabetics at higher risk for crash?" Our searches identified 16 articles that addressed these questions. An assessment of study quality of the included studies found them to be in the low-to-moderate range. While attempts were made to control for differences in the characteristics of individuals that may confound the relationship between diabetes and crash risk in all included studies, most failed to control for exposure. A random-effects metaanalysis found that individuals with diabetes have a $19 \%$ increased risk for a motor vehicle crash when compared to similar individuals without diabetes. We found no compelling evidence to suggest that insulin-treated individuals are at higher risk for motor vehicle crash than individuals with diabetes not being treated with insulin. We discuss the implications of these findings.
\end{abstract}

\section{INTRODUCTION}

It is widely held that individuals with diabetes, particularly insulin-treated diabetics, are at higher risk of crash while driving. This view stems in large part from the well-known acute disabling effects of the disease (e.g., hypoglycemia), as well as longer term health complications (e.g., retinopathy, cardiovascular complications, and neuropathy). While this view is strongly maintained, the supporting evidence is limited. The primary objective of this systematic review was to address the question, "Are drivers with diabetes mellitus at greater risk for a motor vehicle crash than comparable drivers without the disease?" and secondarily, to address the question, "Are insulin-treated diabetics at higher risk for crash?"

\section{METHODS}

This systematic review followed the protocol outlined by Treadwell et al. (2006). Sensitive search strategies, developed and refined by an information specialist, were applied to the following seven electronic databases_-Medline, PubMed (pre Medline), EMBASE, PSYCH 
Info, CINAHL, TRIS, and the Cochrane Library (through May 28, 2006). Additional hand searches of the published literature (i.e., bibliographies of identified relevant articles) and "gray literature" resources (e.g., Web searches) were also performed. Formal a priori criteria for article retrieval and study inclusion consisted of: (1) English language publications, (2) full-length articles, (3) controlled (case-control or cohort) study design, and (4) enrolled $\geq 10$ patients.

The quality of all included studies was determined using a revised version of the Newcastle/Ottawa Scale (Wells, 2000). Random- and fixed-effects meta-analyses were used to pool data from different studies (Hedges, 1994; Raudenbush, 1994). The Q-statistic and $\mathrm{I}^{2}$ were used to identify heterogeneity among the studies' results (Higgins, 2003). Sensitivity analyses, aimed at testing the robustness of our findings, included the use of cumulative fixed- and random-effects meta-analysis (Sterne, 1998). Publication bias was tested for using the "trim and fill" method with funnel plots (Duval \& Tweedie, 2000).

\section{RESULTS}

\section{Evidence Base}

Our searches identified a total of 159 potentially relevant articles, of which 16 were found to meet all inclusion criteria (Table 1). These 16 studies (describing unique datasets) addressed the following key questions:

1) What is the risk ratio for a motor vehicle crash among drivers with diabetes compared to drivers without diabetes (13 studies)?

2) Are drivers with diabetes overrepresented among drivers who have had a crash (3 studies)?

In this review we focus on data extracted and combined from the first group of studies and supplement our findings with data from the smaller data set.

\section{Quality of Evidence Base}

An assessment of study quality using a validated instrument designed for assessing the quality of case-control and cohort studies found the quality of the included studies to be low-to-moderate (Table 2). Attempts were made by study investigators of all studies to control for differences in the characteristics of individuals that may confound the relationship between diabetes and crash risk. However, the majority of included studies failed to control for exposure.

\section{Generalizability of Evidence Base}

One included study (Laberge-Nadeau, 2000) enrolled commercial motor vehicle (CMV) drivers only; the remainder enrolled individuals with a private motor vehicle license. Individuals enrolled in the included studies comprised mixed populations; the majority of studies included individuals with both Type 1 and Type 2 diabetes. Only two studies constricted enrollment to individuals with Type 1 diabetes (Eadington \& Frier, 1989; Songer, 1988). 
Table 1. Evidence base

\begin{tabular}{|c|c|c|c|c|c|c|c|}
\hline 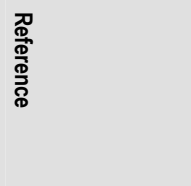 & ঐ & 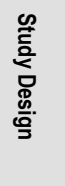 & 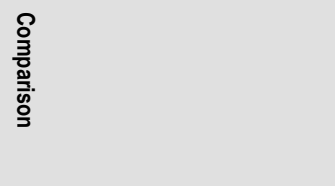 & 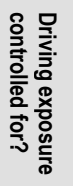 & 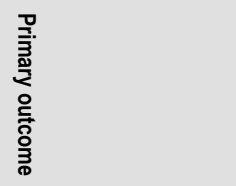 & 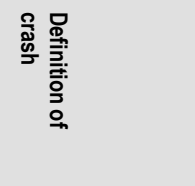 & 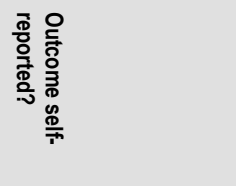 \\
\hline \multicolumn{8}{|c|}{ Studies comparing crash rates among individuals with diabetes and individuals without the disorder (primary data set) } \\
\hline Cox et al. & 2003 & $\operatorname{CCS}$ & $\begin{array}{l}673 \text { individuals with diabetes vs. } \\
363 \text { without diabetes }\end{array}$ & Yes & Difference in crash rate & $\begin{array}{l}\text { Driver in any motor } \\
\text { vehicle crash }\end{array}$ & Yes \\
\hline $\begin{array}{l}\text { Laberge-Nadeau et } \\
\text { al. }\end{array}$ & 2000 & $\operatorname{CCS}$ & $\begin{array}{l}4,495 \text { individuals with diabetes vs. } \\
8,958 \text { without diabetes }\end{array}$ & Yes & Difference in crash rate & $\begin{array}{l}\text { CMV driver in any } \\
\text { motor vehicle crash }\end{array}$ & No (provincial records) \\
\hline $\begin{array}{l}\text { de Klerk \& } \\
\text { Armstrong }\end{array}$ & 1983 & $\operatorname{CCS}$ & $\begin{array}{l}8,623 \text { individuals with diabetes vs. } \\
\text { expected rate (Western Australia) }\end{array}$ & No & Difference in crash rate & $\begin{array}{l}\text { Driver in injurious } \\
\text { motor vehicle crash }\end{array}$ & No (hospital records) \\
\hline Hansotia \& Broste & 1991 & $\operatorname{CCS}$ & $\begin{array}{l}484 \text { individuals with diabetes vs. } \\
30,420 \text { without diabetes }\end{array}$ & No & Difference in crash rate & $\begin{array}{l}\text { Driver in any motor } \\
\text { vehicle crash }\end{array}$ & No (State Records) \\
\hline Stevens et al. & 1989 & $\operatorname{ccs}$ & $\begin{array}{l}354 \text { individuals with diabetes vs. } \\
307 \text { without diabetes }\end{array}$ & No & Difference in crash rate & $\begin{array}{l}\text { Driver in any motor } \\
\text { vehicle crash }\end{array}$ & Yes \\
\hline Eadington \& Frier & 1989 & $\operatorname{CCS}$ & $\begin{array}{l}187 \text { individuals with diabetes vs. } \\
\text { data obtained from DOT and } \\
\text { insurance claims }\end{array}$ & No & Difference in crash rate & $\begin{array}{l}\text { Driver in any motor } \\
\text { vehicle crash }\end{array}$ & Yes \\
\hline Songer et al. & 1988 & CCS & $\begin{array}{l}127 \text { individuals with diabetes vs. } \\
127 \text { without diabetes }\end{array}$ & Yes & Difference in crash rate & $\begin{array}{l}\text { Driver in any motor } \\
\text { vehicle crash }\end{array}$ & Yes \\
\hline Davis et al. & 1973 & $\operatorname{CCS}$ & $\begin{array}{l}108 \text { individuals with diabetes vs. } \\
1,650,245 \text { without diabetes }\end{array}$ & No & Difference in crash rate & $\begin{array}{l}\text { Driver in any motor } \\
\text { vehicle crash }\end{array}$ & No (state records) \\
\hline Ysander & 1970 & CCS & $\begin{array}{l}219 \text { individuals with diabetes vs. } \\
219 \text { without diabetes }\end{array}$ & No & Difference in crash rate & $\begin{array}{l}\text { Driver in any motor } \\
\text { vehicle crash }\end{array}$ & No (state records) \\
\hline Campbell \& Ellis & 1969 & $\operatorname{CCS}$ & $\begin{array}{l}346 \text { individuals with diabetes vs. } \\
346 \text { without diabetes }\end{array}$ & No & Difference in crash rate & $\begin{array}{l}\text { Driver in any motor } \\
\text { vehicle crash }\end{array}$ & No (provincial records) \\
\hline $\begin{array}{l}\text { McMurray \& } \\
\text { Crancer }\end{array}$ & 1968 & $\operatorname{CCS}$ & $\begin{array}{l}7,646 \text { individuals with diabetes vs. } \\
1,600,000 \text { without diabetes }\end{array}$ & No & Difference in crash rate & $\begin{array}{l}\text { Driver in any motor } \\
\text { vehicle crash }\end{array}$ & No (state records) \\
\hline Ysander & 1966 & CCS & $\begin{array}{l}256 \text { individuals with diabetes vs. } \\
256 \text { without diabetes }\end{array}$ & No & Difference in crash rate & $\begin{array}{l}\text { Driver in injurious } \\
\text { motor vehicle crash }\end{array}$ & No (government records) \\
\hline Waller & 1965 & $\operatorname{CCS}$ & $\begin{array}{l}287 \text { individuals with diabetes vs. } \\
922 \text { without diabetes }\end{array}$ & No & Difference in crash rate & $\begin{array}{l}\text { Driver in any motor } \\
\text { vehicle crash }\end{array}$ & No (state records) \\
\hline \multicolumn{8}{|c|}{ Studies comparing prevalence of diabetes among crashers and non-crashers (secondary data set) } \\
\hline McGwin et al. & 1999 & CCS & $\begin{array}{l}249 \text { individuals at-fault crash vs. } \\
454 \text { individuals no-crash }\end{array}$ & Yes & $\begin{array}{l}\text { Difference in } \% \text { of } \\
\text { individuals with diabetes }\end{array}$ & $\begin{array}{l}\text { Driver in at-fault } \\
\text { crash }\end{array}$ & $\begin{array}{l}\text { Yes (telephone } \\
\text { questionnaire) }\end{array}$ \\
\hline Gressert \& Meyer & 1994 & $\operatorname{ccs}$ & $\begin{array}{l}1,400 \text { individuals injurious crash vs. } \\
2,636 \text { individuals no-crash }\end{array}$ & Yes & $\begin{array}{l}\text { Difference in } \% \text { of } \\
\text { individuals with diabetes }\end{array}$ & $\begin{array}{l}\text { Driver in injurious } \\
\text { motor vehicle crash }\end{array}$ & No (provincial records) \\
\hline Koepsell et al. & 1994 & CCS & $\begin{array}{l}234 \text { individuals injured in crash vs. } \\
446 \text { not involved in crash }\end{array}$ & Yes & $\begin{array}{l}\text { Difference in } \% \text { of } \\
\text { individuals with diabetes }\end{array}$ & $\begin{array}{l}\text { Driver in injurious } \\
\text { motor vehicle crash }\end{array}$ & $\begin{array}{l}\text { No (health insurance } \\
\text { and police records) }\end{array}$ \\
\hline
\end{tabular}

CCS=case-control study

\section{RESULTS}

Data from the 13 studies that compared crash risk in drivers with diabetes to comparable drivers without the disease were found to be homogeneous $\left(\mathrm{I}^{2}=13.9 \%\right.$; $\left.=18.2, P=0.1110\right)$. This finding suggests that the differences in the design, conduct, and populations used for these studies had little impact on outcome. A fixed effects meta-analysis (Figure 1) showed that individuals with diabetes are at a significantly increased risk for a motor vehicle crash $(\mathrm{RR}=1.19,95 \% \mathrm{CI}$ : 1.08 1.32). In other words, the crash risk for diabetic drivers is 1.19 times greater than the risk for comparable drivers without diabetes. A series of sensitivity analyses found this finding to be robust with none of these analyses overturning the findings of the original analysis. No evidence of publication bias was found. 
Table 2. Quality of evidence base

\begin{tabular}{|c|c|c|c|c|c|}
\hline Reference & Year & \multicolumn{2}{c|}{ Quality Scale Used } & Quality Score & Quality \\
\hline \hline \multicolumn{7}{|c|}{ Studies comparing crash rates among individuals with diabetes and individuals without the disorder (primary data set) } \\
\hline \hline Cox et al. & 2003 & Revised Newcastle-Ottawa Quality Assessment Scale & 8.5 & Moderate \\
\hline Laberge-Nadeau et al. & 2000 & Revised Newcastle-Ottawa Quality Assessment Scale & 9.4 & Moderate \\
\hline de Klerk \& Armstrong & 1983 & Revised Newcastle-Ottawa Quality Assessment Scale & 6.3 & Low \\
\hline Hansotia \& Broste & 1991 & Revised Newcastle-Ottawa Quality Assessment Scale & 5.4 & Low \\
\hline Stevens et al. & 1989 & Revised Newcastle-Ottawa Quality Assessment Scale & 7.0 & Low \\
\hline Eadington \& Frier & 1989 & Revised Newcastle-Ottawa Quality Assessment Scale & 7.7 & Low \\
\hline Songer et al. & 1988 & Revised Newcastle-Ottawa Quality Assessment Scale & 7.9 & Low \\
\hline Davis et al. & 1973 & Revised Newcastle-Ottawa Quality Assessment Scale & 5.8 & Low \\
\hline Ysander et al. & 1970 & Revised Newcastle-Ottawa Quality Assessment Scale & 8.1 & Moderate \\
\hline Campbell \& Ellis & 1969 & Revised Newcastle-Ottawa Quality Assessment Scale & 6.5 & Low \\
\hline McMurray \& Crancer & 1968 & Revised Newcastle-Ottawa Quality Assessment Scale & 4.2 & Low \\
\hline Ysander & 1966 & Revised Newcastle-Ottawa Quality Assessment Scale & 7.1 & Low \\
\hline Waller & 1965 & Revised Newcastle-Ottawa Quality Assessment Scale & 7.1 & Low \\
\hline \hline \multicolumn{7}{|l|}{ Studies comparing prevalence of diabetes among crashers and non-crashers (secondary data set) } \\
\hline \hline McGwin et al. & 1999 & Revised Newcastle-Ottawa Quality Assessment Scale & 10.0 & Moderate \\
\hline Gressert \& Meyer & 1994 & Revised Newcastle-Ottawa Quality Assessment Scale & 7.8 & Low \\
\hline Koepsell et al. & 1994 & Revised Newcastle-Ottawa Quality Assessment Scale & 9.4 & Moderate \\
\hline
\end{tabular}

\begin{tabular}{lcccrrr}
\cline { 1 - 5 } Study name & \multicolumn{5}{c}{ Statistics for each study } \\
\cline { 1 - 6 } & $\begin{array}{l}\text { Rate } \\
\text { ratio }\end{array}$ & $\begin{array}{c}\text { Lower } \\
\text { limit }\end{array}$ & $\begin{array}{c}\text { Upper } \\
\text { limit }\end{array}$ & Z-Value & p-Value \\
Cox & 1.954 & 0.796 & 4.798 & 1.462 & 0.144 \\
Laberge-Nadeau & 1.073 & 0.882 & 1.305 & 0.700 & 0.484 \\
De Klerk & 1.522 & 0.845 & 2.740 & 1.400 & 0.162 \\
Hansotia & 1.323 & 1.088 & 1.610 & 2.800 & 0.005 \\
Stevens & 0.932 & 0.664 & 1.309 & -0.404 & 0.686 \\
Eadington & 0.538 & 0.198 & 1.461 & -1.216 & 0.224 \\
Songer & 2.664 & 0.796 & 8.919 & 1.590 & 0.112 \\
Davis & 1.041 & 0.369 & 2.936 & 0.076 & 0.940 \\
Ysander (1970) & 0.583 & 0.254 & 1.338 & -1.273 & 0.203 \\
Campbell & 1.716 & 1.160 & 2.540 & 2.700 & 0.007 \\
Crancer & 1.185 & 0.974 & 1.442 & 1.700 & 0.089 \\
Ysander (1966) & 0.651 & 0.170 & 2.493 & -0.627 & 0.531 \\
Waller & 1.786 & 0.760 & 4.197 & 1.331 & 0.183 \\
& 1.194 & 1.082 & 1.318 & 3.537 & 0.000
\end{tabular}

Rate ratio and $95 \% \mathrm{Cl}$

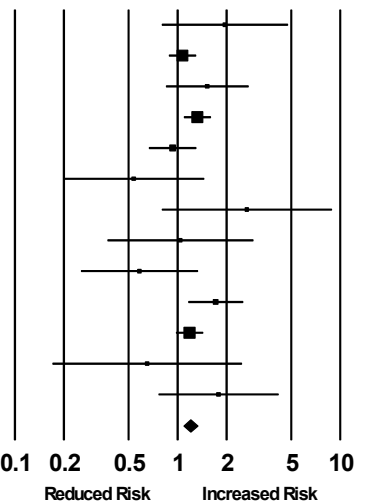

\section{Figure 1. Crash risk in drivers with diabetes relative to drivers without diabetes}

Having determined that drivers with diabetes are at an elevated risk for a motor vehicle crash, we next attempted to determine whether there were any specific subgroups of drivers with diabetes who were at greater risk for crash. In particular, we were interested in determining whether insulin-treated diabetic drivers were at a higher risk than individuals treated using either oral hypoglycemic agents or diet alone. The primary risk factor for a crash among individuals with diabetes is traditionally thought to be hypoglycemia. As there is a reasonably large body of literature showing that hypoglycemia occurs more often among individuals treated with insulin than among those treated by pharmacotherapy or diet alone, one might reasonably expect to observe that individuals with insulin-treated diabetes are at higher risk for a motor vehicle crash when compared with individuals who control their diabetes by other means. Five of the 13 
included studies provided separate crash risk data for drivers who were insulin-treated (Cox, 2003; Eadington \& Frier, 1989; Laberge-Nadeau, 2000; Songer, 1988; Stevens, 1989) allowing us to estimate of the risk ratio associated with this subpopulation of drivers.

Included among the five studies cited above was the study of Laberge-Nadeau et al. (2000). This study specifically assessed crash risk among CMV drivers with diabetes. In so doing, these investigators presented data separately for articulated and straight truck drivers. Making an assumption that the latter two data sets can be considered independent of one another (although sampled from the same database, the two groups consist of a different set of cases and controls), we treated them as if they were two separate studies. Consequently, a total of six data sets containing information on crash risk among drivers with insulin-dependent diabetes were available for analysis. These data were found to be heterogeneous $\left(\mathrm{I}^{2}=68.97 \% ; \mathrm{Q}=16.11\right.$, $P=0.0065$ ). Data from a heterogeneous data set cannot be combined in a fixed-effects metaanalysis because such a synthesis is in violation of the model's underlying assumption of homogeneity. Instead, we pooled the available risk-ratio data using random-effects metaanalysis, which allows one to combine heterogeneous data by partitioning the estimated between-studies variance component and adding it to the within-studies variance of each included study (Raudenbush, 1994).

The results of this meta-analysis, which is presented in Figure 2, does not provide evidence supporting the contention that the risk for a motor vehicle crash is significantly higher among individuals with insulin-treated diabetes $(\mathrm{RR}=1.11,95 \% \mathrm{CI}: 0.80-1.80, P=0.676)$. Likewise, separate meta-analyses of subsets of data from three studies that compared the odds of having diabetes among a group of individuals who experienced a crash, with the odds of having diabetes among individuals who did not crash, failed to demonstrate that individuals with insulin-treated diabetes represent a population who are at higher risk for crash (Figure 3).

Study name
Cox
Laberge-Nadeau (AT)
Laberge-Nadeau (ST)
Stevens
Eadington
Songer

\begin{tabular}{lccrrr}
\multicolumn{5}{c}{ Statistics for each study } \\
\cline { 3 - 5 } $\begin{array}{c}\text { Rate } \\
\text { ratio }\end{array}$ & $\begin{array}{c}\text { Lower } \\
\text { limit }\end{array}$ & $\begin{array}{c}\text { Upper } \\
\text { limit }\end{array}$ & Z-Value & p-Value \\
2.387 & 1.421 & 4.009 & 3.288 & 0.001 \\
0.651 & 0.350 & 1.209 & -1.360 & 0.174 \\
1.020 & 0.444 & 2.343 & 0.047 & 0.962 \\
0.932 & 0.664 & 1.309 & -0.404 & 0.686 \\
0.538 & 0.198 & 1.461 & -1.216 & 0.224 \\
2.664 & 0.796 & 8.919 & 1.590 & 0.112 \\
1.111 & 0.683 & 1.808 & 0.424 & 0.672
\end{tabular}

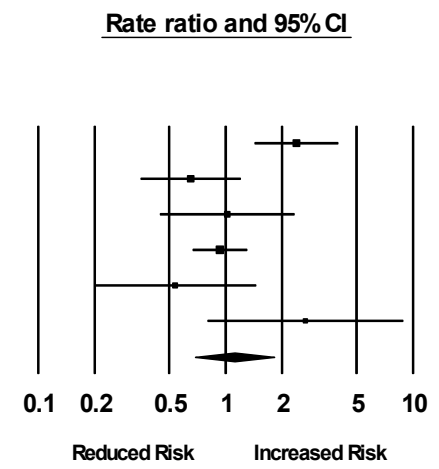

Figure 2. Random effects meta-analysis of crash data from insulin-treated cohorts

\section{DISCUSSION}

Drivers with diabetes mellitus are at 19 percent greater risk for a motor vehicle crash than drivers who do not have diabetes. This is important from a public policy perspective because diabetes is a highly prevalent condition with approximately 29 million people or $14.4 \%$ of those over 20 years old with diagnosed diabetes, undiagnosed diabetes, or impaired fasting glucose (Centers for Disease Control and Prevention [CDC], 2003). 


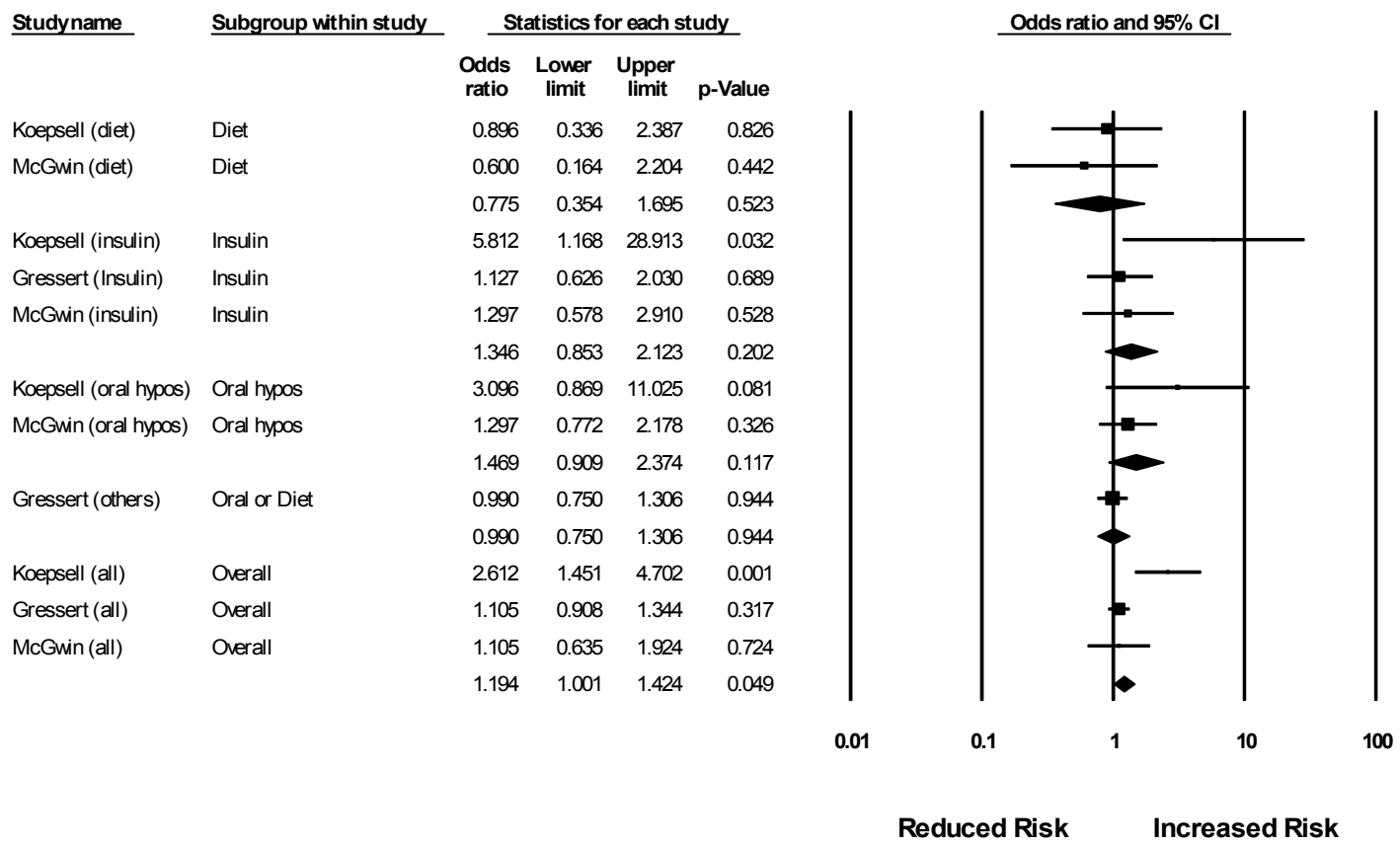

Figure 3. Results of analyses of data from studies of prevalence of diabetes among crashers and non-crashers

Drivers with diabetes are a heterogeneous group with a variety of potential mechanisms that could increase crash risk, in association with both acute and chronic medical complications of diabetes. The critical task is to identify subsets of drivers with diabetes who are at greatest risk for a crash. One such subset that might be suspected of having an increased crash risk is those who are subject to hypoglycemia, a potentially debilitating condition that affects both individuals with Type 1 and Type 2 diabetes. It is believed that insulin treated individuals (all those with Type 1 diabetes and a minority of those with Type 2 diabetes) are at an increased risk for hyperglycemia and hence, crash. Our analyses found no statistically significant evidence to suggest that insulin-treated individuals represent a higher risk subgroup of individuals with diabetes. However, because of the small size of the evidence base (low power) and the possibility that the insulin-treated individuals in the included studies are not representative of all insulin-treated individuals who drive, one cannot construe this finding as providing conclusive evidence that individuals with insulin-treated diabetes are not at greater risk for a crash than noninsulin treated individuals.

The findings of this review underscore the need for additional quality research on driving performance, safety errors, vehicle crashes, and countermeasures in drivers with different complications of diabetes. Relevant research can address driving safety issues related to problems of: 1) vision (e.g., diabetic retinopathy affecting acuity, contrast sensitivity and fields); 2) cognition (e.g., attention, perception, memory and executive function), mood and arousal due to metabolic encephalopathy (e.g., with glucose shifts or renal disease) or cerebrovascular disease; 3) cardiac and peripheral vascular disease; 4) neuropathy (with numbness and weakness affecting control over the pedals); 5) side-effects of medicines; and 6) reduced self-awareness of physiologic and performance impairments caused by these factors. 


\section{ACKNOWLEDGMENTS}

This article was prepared from United States Department of Transportation data, supported by contract number GS-10F-0177N/DTMC75-05-F-00062. The opinions of the authors expressed herein do not necessarily state or reflect those of the United States Government.

\section{REFERENCES}

Campbell, E.O., \& Ellis, K.G. (1969). Chronic medical conditions and traffic violation and accident experience of diabetic drivers. Mod Med Can, 24(11), 29-31.

Centers for Disease Control and Prevention (CDC). (2003). Prevalence of diabetes and impaired fasting glucose in adults-United States, 1999-2000. MMWR Morb Mortal Wkly Rep, 52, 833-7.

Cox, D.J., Penberthy, J.K., Zrebiec, J., Weinger, K., Aikens, J.E., Frier, B., et al. (2003). Diabetes and driving mishaps: frequency and correlations from a multinational survey. Diabetes Care, 26, 2329-34.

Davis, T.G., Wehling, E.H., \& Carpenter, R.L. (1973). Oklahoma's medically restricted drivers. A study of selected medical conditions. J Okla State Med Assoc, 66, 322-7.

de Klerk, N.H., \& Armstrong, B.K. (1983). Admission to hospital for road trauma in patients with diabetes mellitus. J Epidemiol Community Health, 37, 232-7.

Duval, S.J., \& Tweedie, R.L. (2000). A non-parametric 'trim and fill' method of assessing publication bias in meta-analysis. J Am Stat Assoc, 95(449), 89-98.

Eadington, D.W., \& Frier, B.M. (1989). Type 1 diabetes and driving experience: an eight-year cohort study. Diabet Med, 6, 137-41.

Gresset, J., \& Meyer, F. (1994). Risk of automobile accidents among elderly drivers with impairments or chronic diseases. Can J Public Health, 85, 282-5.

Hansotia, P., \& Broste, S.K. (1991). The effect of epilepsy or diabetes mellitus on the risk of automobile accidents. $N$ Engl J Med, 324(1), 22-6.

Hedges, L.V. (1994). Fixed effects models. In H. Cooper, L.V. Hedges (Eds.), The handbook of research synthesis. New York: Russell Sage Foundation, 285-99.

Higgins, J.P., Thompson, S.G., Deeks, J.J., \& Altman, D.G. (2003). Measuring inconsistency in meta-analyses. $\mathrm{Br} \mathrm{Med} J, 327,557-60$.

Koepsell, T.D., Wolf, M.E., McCloskey, L., Buchner, D.M., Louie, D., Wagner, E.H., et al. (1994). Medical conditions and motor vehicle collision injuries in older adults. J Am Geriatr Soc, 42, 695-700.

Laberge-Nadeau, C., Dionne, G., Ekoe, J.M., Hamet, P., Desjardins, D., Messier, S., et al. (2000). Impact of diabetes on crash risks of truck-permit holders and commercial drivers. Diabetes Care, 23, 612-7.

McGwin, G. Jr, Sims, R.V., Pulley, L., \& Roseman, J.M. (1999). Diabetes and automobile crashes in the elderly. A population-based case-control study. Diabetes Care, 22, 220-7. 
McMurray, L., \& Crancer, A. Jr. (1968). Accident and violation rates of Washington's medically restricted drivers. $J A M A, 205,272-6$.

Raudenbush, S.W. (1994). Random effects models. In H. Cooper, L.V. Hedges (Eds.), The handbook of research synthesis. New York: Russell Sage Foundation, 301-21.

Songer, T.J., LaPorte, R.E., Dorman, J.S., Orchard, T.J., Cruickshanks, K.J., Becker, D.J., et al. (1988). Motor vehicle accidents and IDDM. Diabetes Care, 11, 701-7.

Sterne, J. (1998). sb22: cumulative meta-analysis. Stata Technical Bulletin, 42, 13-6.

Stevens, A.B., Roberts, M., McKane, R., Atkinson, A.B., Bell, P.M., \& Hayes, J.R. (1989). Motor vehicle driving among diabetics taking insulin and non-diabetics. $\mathrm{Br} M e d \mathrm{~J}$ (Clin Res $E d), 299$, 591-5.

Treadwell, J.T., Tregear, S.J., Reston, J.T., \& Turkelson, C.M. (2006). A system for rating the stability and strength of medical evidence. BMC Med Res Methodol, 6, 52.

Waller, J.A. (1965). Chronic medical conditions and traffic safety: review of the California experience. $N$ Engl J Med, 273, 1413-20.

Wells, G.A., Shea, B., O'Connell, D., Peterson, J., Welch, V., \& Tugwell, P. (2000). The Newcastle-Ottawa Scale (NOS) for assessing the quality of non-randomised studies in metaanalyses. In 3rd Symposium on Systematic Reviews: Beyond the Basics. Oxford, England.

Ysander, L. (1966). The safety of drivers with chronic disease. Br J Ind Med, 23(1), 28-36.

Ysander, L. (1970). Diabetic motor-vehicle drivers without driving-license restrictions. Acta Chir Scand Suppl, 409, 45-53. 